\title{
Construction of CHP using public-private partnership
}

\author{
Ekaterina Nikonova ${ }^{1}$, Anna Chursina ${ }^{1}$, Aleksey Sindeev ${ }^{1}$, and Aleksey Letunovskiy ${ }^{*}$ \\ ${ }^{1}$ Moscow State University of Civil Engineering, Yaroslavskoe shosse, 26, Moscow, 129337, Russia
}

\begin{abstract}
The paper presents the concept of public-private partnership that is a relatively innovative mechanics, which serves to combine the investments of the state and free enterprise in the implementation of large infrastructure projects. For Russia, it is strategically important and relevant to remain independent in the field of energy. The energy sector requires introduction of innovative facilities and modernization of facilities that are in operation A growing understanding of the urgency of the problem of budgetary investment volumes makes the state look for alternative financing mechanisms. The coordination of interests is an integral part of the interaction of the state and business in the framework of public-private partnership. The state is mainly interested in the implementation of strategic plans for the development of the energy field, as well as improving the quality and increasing the amount of services. The investors are interested in obtaining a stable refundability on investment. In these conditions, public-private partnership is the most relevant form of implementation of large investment projects in Russia. The ratio of costs and the results obtained expresses the concept of efficiency. However, public-private partnership projects are difficult to evaluate and ambiguous. For each of the participants, performance evaluation has a different nature and includes various indicators. During the life cycle of projects, the interaction conditions and risks that accompany the project may change.
\end{abstract}

\section{Introduction}

Nowadays, there are various models and structures of public-private partnership (PPP) [1]. For Russia, it is strategically important and relevant to remain independent in the field of energy. The energy sector requires introduction of innovative facilities and modernization of facilities that are in operation [2]. Increasing energy production is not enough, it also requires replacing outdated and worn-out equipment. Depreciation of equipment in the power industry may lead to a decrease in efficiency and even to a decrease in reliability to unacceptable levels.

The combined heat and power plant (CHP) is a type of thermal power plant that is a source of not only electrical energy, but also heat in centralized heat supply systems [3]. Energy comes in the form of steam and hot water, which also provides hot water and heating homes and industrial facilities. Energy is one of the most relevant economic areas

\footnotetext{
${ }^{*}$ Corresponding author: letaleks2@mail.ru
} 
of activity. There are a large number of natural and artificial subsystems that are able to transform, distribute and use resources of various kinds. In Russia, the efficiency of CHP is approximately $36.6 \%$ as compared to the world's $39 . .41 .5 \%$. Therefore, the investment support and partnership of the state and private entrepreneurs in the field of construction of new CHP is a relevant problem [4].

\section{Research methods}

A large number of topical issues are confronting foreign companies, mainly related to the peculiarities of performing work in the current legal, political and technical field of the Russian energy construction. Such issues include the need for membership in SROs, certification of foreign equipment, Russian standards in the field of design and construction, the legal framework and the particular mentality of customers. All participants in the energy construction market (general contractors, designers, builders) are required to have an SRO permit to operate in the territory of the Russian Federation. The regulation of the formation and activities of self-regulatory organizations is provided by the Law No.315F3 "On self-regulatory organizations".

Shifting control functions from the state to the market participants themselves is the main idea of self-regulatory organizations [5]. State control over the result replaced control over activities. The consequence of the introduction of such a mechanism may be the gradual abolition of licensing for certain types of activities. It is necessary to pay the fee and pass certification for equipment produced outside the territory of Russia. The State Standard for Metrology and Certification (EAS) adopted by the Interstate Council for Standardization is applied in Russia and the CIS countries. In the Russian Federation, the concepts of "technical regulation" and "standard" are separated by the law on technical regulation No. 184-PL. Before technical regulations are adopted in certain industries [6], GOST must be followed. The new edition of the "Regulations on the Federal Information Fund for Technical Procedure and Standards" and the unified information system for technical regulation was approved by Government Decree No. 966. Reducing differences in Russian norms, standards of the European Union and building design standards (Eurocodes) is the main task.

However, the most successful national norms and standards of other foreign countries must be taken into account [7]. In our time, the "Strategy for the development of power engineering until 2030" is particularly relevant. This strategy focuses on the development of industrial policy, which exists in many developed European countries, not on prohibitive measures [8]. Specific tariff and non-tariff measures are aimed at encouraging foreign and Russian participants to increase the number of investments in the creation of production facilities and the development of R \& D in the territory of the Russian Federation. Some innovative technologies in the field of energy [9], which are just beginning to be introduced in Russia, are already actively used in the United States and Europe.

However, the Russian power plant factories have the capacity to provide about a third of the needs of the local market, but often lose in terms of efficiency and environmental performance. As an example, the technology of combined-cycle plants (CCGT) originates in Russia, but is widely spread primarily in the West [10]. As a result, the share of imported equipment in the actual CCGT in the Russian energy market is $30 \ldots 50 \%$, since domestic manufacturing plants do not have the ability to produce it themselves. The reason for this situation is the excessively small amount of investment since the $90 \mathrm{~s}$. When considering the export of gas turbines of medium and high power (from $200 \mathrm{MW}$ ), the West and China are clearly leading. In recent years, the import of this equipment has been widespread. The West is inferior in price to China, and China, in turn, in quality. Achieving quality at the 
West level in this area seems unlikely, at least for now. Basically, foreign companies are not against giving only part of the production under a license.

\section{Results}

The most logical decision in terms of development for Russia would be to organize the licensed production of GTU. In this case, the generating companies will have no choice but to use foreign turbines or turbines manufactured in Russia, but under license from foreign manufacturers. In the field of boiler building and the production of electrical equipment, the situation is also relevant. The lack of investment has also had an impact on this industry. Russian companies are forced to acquire licenses for the design, manufacture and installation of waste heat boilers from foreign manufacturers.

In the field of the construction of pulverized coal boilers for supercritical parameters, steam turbines and generators, the situation is better. In the market of this industry there are competitive solutions from domestic manufacturers.

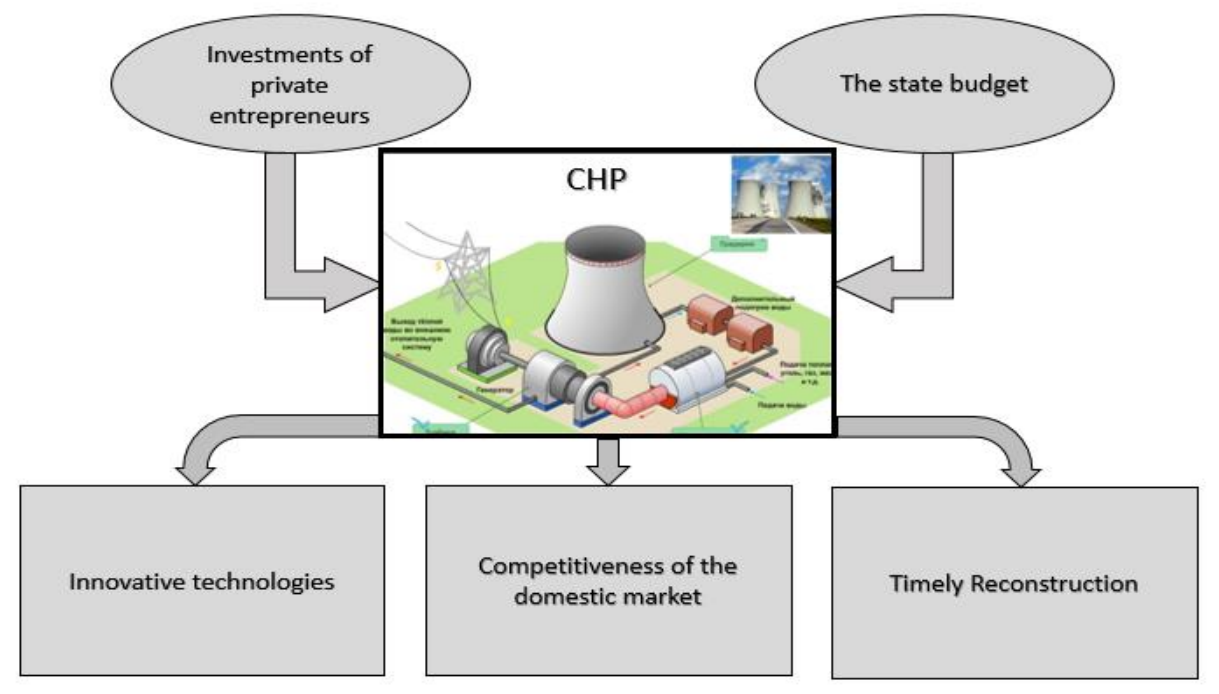

Fig. 1. Diagram of predicted results of PPP.

In the course of the reform, the electric power industry was divided into potentially competitive (generation and sales) [11] and natural monopoly (transmission, distribution and dispatching). Such a division by activity provided opportunities for the application of unique investment mechanisms [12]. Private investment takes a leading position. However, in the monopoly sector, owned by the state and subject to tariff regulation, long-term credit resources, tariff revenues and budget funds are used as a source of investment. At the same time, it is necessary not to forget the differences of electric power industry enterprises by type of activity and form of ownership (private and public).

The mechanism of public-private partnership (PPP) helps to solve the problems of regional and interregional development of energy infrastructure [13]. Solving the problem of replacing worn-out equipment and improving the efficiency of managing infrastructure projects is possible by attracting funds from private investors. But the creation of an effective model of public-private partnership under the current legislation is the basis for the successful implementation of projects. And the development of a financial model would ensure mutually beneficial cooperation of private investors and executive authorities, as well as the refundability of investment. Public-private partnerships can be applied as the 
interaction of state and business, mainly in those areas in which the state is the owner, willing to attract private enterprises to achieve relevant investment goals [14]. This is what allows the power industry to be one of the most promising areas for the use of publicprivate partnerships, as this industry contains companies with state participation, and there are also need for innovations. Therefore, the distribution of certain functions [15] to private enterprises in the framework of public-private partnership improves the quality and efficiency of services, improves cost control, ensures the availability of innovative technologies and management methods, which in turn ensures a reduction in budget expenditures [16]. The coordination of interests is an integral part of the interaction of the state and business in the framework of public-private partnership. The state is mainly interested in the implementation of strategic plans for the development of the energy field, as well as improving the quality and increasing the amount of services. The investors in their turn are interested in obtaining a stable refundability on investment. Thus, the both parties are interested in the successful implementation of investment projects.

The basic signs of a public-private partnership are [17]:

- two sides of public-private partnerships: the state and private business;

- the interaction of the parties is on a legal basis;

- equal interaction between the parties;

- pooling resources and contributions of both parties in the implementation of projects;

- financial risks, costs and benefits are distributed among partners in certain proportions.

The following distinctive features of public-private partnership are noted [18]:

1. Terms of contracts can be 10-20 years, and in some cases up to 50 .

2. Unique types of financing programs. The projects are implemented through the investment of private enterprises in conjunction with state funds.

3. Competitive standoff. The fight between potential bidders for contracts.

4. Distribution of responsibility between participants in unique forms. On the part of the state, it is the setting of goals from the standpoint of public interest, as well as the establishment of quality and cost indicators, and the monitoring of program implementation. On the private side, development, financing, management, construction and operation.

5. Conclusion of agreements on the distribution of risks between the parties.

\section{Discussion}

The ratio of costs and the results obtained expresses the concept of efficiency [19]. However, public-private partnership projects are difficult to evaluate and ambiguous. For each of the participants, performance evaluation has a different nature and includes various indicators. Also during the life cycle of projects, the interaction conditions and risks that accompany the project may change [20].

Evaluation of the effectiveness of the project of public-private partnerships is carried out in the following areas:

- calculation of how profitable it is to attract a private enterprise in relation to the project without such involvement;

- identifying and assessing all types of risks and determining the form of managing them in

- the process of implementing a public-private partnership project;

- full business case for public-private partnerships.

Evaluation of the effectiveness of public-private partnership projects consists of three stages:

The first stage consists in the qualitative assessment of a public-private partnership project. At this stage, an information base is formed on project implementation and its 
program. A feasibility analysis of the proposed project is also being developed based on the data obtained.

The second stage is to form decisions about the benefits of partnerships, based on a variety of efficiency categories, such as the effectiveness of the project as a whole and the effectiveness of participation in the project.

The third stage consists of a direct assessment of the feasibility of the project on quantitative aspects (finance, economy).

\section{Conclusion}

Thus, in the energy sector in Russia there is a lack of funding. Public-private partnerships have all the necessary makings to solve most of the investment problems, and, consequently, improve efficiency and safety in this area. It is also possible to increase the degree of electrification in remote areas by attracting private enterprises to the realization of investment programs. Attracting private investors will provide quality service and timely reconstruction, which will increase the reliability of energy supply.

\section{References}

1. H. Strauss, Evolution and Economics of Private Infrastructure Finance 15-1, 643 (2010)

2. An EU strategy on heating and cooling (Brussels, European Commission, 2016)

3. A. Verbruggen, P. Dewallef, S. Quoilin, M. Wiggin, Energy, Springer International Publishing, 575-582 (2016)

4. E. Auriol, P.M. Picard, The Economic Journal 119, 1464-1493 (2009)

5. A. Oppio, F. Torrieri, Social and Behavioral Sciences, Elsevier 223, 62-68 (2016)

6. M. Jefferies, W.D. McGeorge, Construction and Architectural Management, Emerald Group Publishing Limited 16(5), 415-437 (2009)

7. C. Greve, G. Hodge, 1st Global Conference on Transparency Research, Rutgers University, 153-159 (2011)

8. S. Issouf, S.L. Van, Economic Modelling, Elsevier 59, 508-519 (2016)

9. J. Kotowicz, M. Job, M. Brzeczek, Energy, Elsevier 92, 197-211 (2015)

10. R. Kehlhofer, F.S. Hannemann, B. Rukes, Combined-Cycle Gas\&Steam Power Plants (Pennwell, USA, 2009)

11. K.D. Pawluskiewicz, T. Hoang, International Journal of Smart Grid and Clean Energy, Engineering and Technology Publishing 5-2, 77-85 (2016)

12. S. Garg, S. Garg, Transportation Research Procedia, Elsevier 25, 3789-3807 (2017)

13. V. Khmel, S. Zhao, IATSS Research, International Association of Traffic and Safety Sciences, Tokyo 39-2, 138-145 (2016)

14. S. Staropoli, S. Staropoli, C. Staropoli, A. Yvrand-Billon, Review of Industrial Organization, Springer 35-1, 1-18 (2009)

15. T. Liu, Y. Wang, S. Wilkinson, A comparative analysis of Australia and China International Journal of Project Management, Elsevier 34-4, 701-716 (2016)

16. Y. Wang, Public Administration Review, Wiley 69-4, 779-782 (2009)

17. Y. Jingfeng, Y.A. Zeng, J.M. Skibniewski, Q. Li, Construction Management and Economics, Taylor \& Francis (Routledge) 27-3, 253-270 (2009) 
18. C. Cui, Y. Liu, A. Hope, International Journal of Project Management, Elsevier 36-5, 773-794 (2018)

19. J. Forrer, E. Kee, E.K. Newcomer, E. Boyer, Public-Private Partnerships and the Public Accountability Question, 12 (2010)

20. A. Chaurey, P.R. Krithika, D. Palit, S. Rakesh, K.B. Sovacool, Energy Policy, Elsevier 47, 48-55 (2012)

21. A. Slavin, S. Sinenko, N. Yoshin, The evolutionary development of the methodology of operational planning of construction production, 365-6 (2018)

22. S. Sinenko, T. Poznakhirko, Summarizing progressive approaches to choosing organizational and technological solutions for the construction of buildings, 193 (2018)

23. A. Volkov, V. Chulkov, R. Kazaryan, Functions and organizational forms of graphicimage modeling of knowledge, 91 368-372 (2014) 